\title{
Acute bronchitis and clinical outcome three years later: prospective cohort study
}

\author{
Jón Steinar Jónsson, Thorarinn Gíslason, Davíd Gíslason, Jóhann A Sigurdsson
}

Acute bronchitis is a common disorder ${ }^{1}$ usually assumed to be caused by a viral infection ${ }^{2}$ with no beneficial effect resulting from antibiotic treatment. ${ }^{3}$ We examined whether acute bronchitis in a healthy individual should be regarded as an isolated event or a predictor of chronic lung disorders that has not yet clearly manifested itself clinically-that is, as bronchial hyperresponsiveness, asthma, or chronic bronchitis.

\section{Material, methods, and results}

In a previous study on the aetiology of acute bronchitis among adults in Gardabaer (7800 inhabitants), a suburban town south of Reykjavik, all patients diagnosed with acute bronchitis were included. ${ }^{4}$ The definition of acute bronchitis in that study was: cough (with or without expectoration) and rhonchi or coarse rales on auscultation in patients without any known underlying lung disease (according to the patients' medical records) or clinical signs of pneumonia. That prised 138 patients. Three years later, in 1995-6, the original study group still living in Gardabaer $(n=119)$ was invited to take part in the present study.

We sent these patients a questionnaire with the same questions as used in the Icelandic version of the European community respiratory health survey ${ }^{5}$ about respiratory symptoms, along with some additional questions. All were invited to participate in an examination with spirometry, a methacholine challenge test, and a skin prick test. If patients did not return the questionnaire, information about asthma and recurrent acute bronchitis was collected from medical records.

Ninety five of the $119(80 \%)$ subjects (44 men, 51 women) returned the questionnaire. The respondents were significantly older than the non-respondents $(45$ (range 31-59) years $v 34(23-45)$ years; $\mathrm{P}<0.001)$. Twenty patients smoked daily, 11 smoked less than daily, 29 were former smokers, and 35 had never smoked. Respiratory symptoms indicating asthma and/or chronic bronchitis were commonly reported (table).

Six per cent $(5 / 85)$ patients had a forced expiratory volume in one second of below $80 \%$ of that predicted. On methacholine challenge tests a reduction of $20 \%$ or more in forced expiratory volume in one second was observed among $8 \%(6 / 74)$ of patients after inhalation of the saline solution and among a further 22\% (16/74) after inhalation of $2 \mathrm{mg}$ or less of methacholine.

Seven patients reported wheezing during the preceding 12 months and showed bronchial hyperresponsiveness. Another 11 patients had been diagnosed by doctors as having asthma. Thus three years after seeing a doctor for an uncomplicated episode of acute bronchitis, at least 18 patients (19\%) fulfilled criteria for asthma. Twenty patients reported having brought up phlegm on most days for at least three months every year, a criteria often used to define chronic bronchitis in epidemiological studies. Six of these 20 also fulfilled criteria for asthma. Therefore $32(18+20-6)$ patients prospective study was carried out in 1992-3 and com-

\begin{tabular}{lc}
$\begin{array}{lc}\text { Characteristics of study population and main findings } \\
\text { Characteristic }\end{array}$ & $\begin{array}{c}\text { No of } \\
\text { patients }\end{array}$ \\
\hline Original study population & 138 \\
\hline Moved away three years later & 19 \\
\hline Available for study & 119 \\
\hline Returned questionnaires & 95 \\
\hline Available for spirometry and skin prick testing & 85 \\
\hline Able to undergo methacholine challenge with no contraindication & 74 \\
\hline Main results from questionnaire & \\
\hline Wheezing or whistling in chest at any time in past 12 months: & $38 / 95$ \\
\hline Breathless when wheezing or whistling noise was present & $19 / 38$ \\
\hline Wheezing or whistling present in absence of a cold & $17 / 38$ \\
\hline Phlegm brought up from chest during day, at night, or in winter: & $22 / 95$ \\
\hline Similar phlegm most days for up to 3 months each year & $20 / 22$ \\
\hline Diagnosis of asthma by doctor & $11 / 95$ \\
\hline Wheezing and positive methacholine test & $7 / 74$ \\
\hline
\end{tabular}

(34\%) fulfilled criteria for asthma or chronic bronchitis, or both. According to medical records, bronchial asthma had been diagnosed in 13\% (3/24) of the nonrespondents. Only $12(13 \%)$ respondents had at least one positive skin prick test.

\section{Comment}

Using a simple questionnaire about pulmonary symptoms, together with spirometry and methacholine challenge testing, we found that $34 \%$ of the original study group fulfilled criteria for asthma or chronic bronchitis, or both.

We suggest therefore that when doctors see a patient with acute bronchitis, they should always consider possible bronchial hyperresponsiveness, asthma, or chronic bronchitis and use simple investigation methods-that is, inquire about symptoms and carry out spirometry (and in some cases methacholine challenge testing). In addition, they should inform the patient of the risk of developing chronic lung disease. This may help doctors to choose the best treatment and motivate the patient to eliminate possible risk factors, such as smoking.

Contributors: JSJ had the original idea and is guarantor for the study. JSJ and TG wrote the study protocol. JSJ collected the data. TG and DG were responsible for the lung function and skin prick tests. All authors collaborated in writing the paper. biological and medical sciences in the Icelandic Council of Science, the Oddur Ólafsson Scientific Fund, and the Research Fund of the Association of Icelandic Family Physicians.

Competing interests: None declared.

1 Verheij TJM, Kaptein AA, Mulder JD. Acute bronchitis: aetiology, symptoms and treatment. Fam Pract 1989:6:66-9.

2 Gonzales R, Sande M. What will it take to stop physicians from prescribGonzales R, Sande M. What will it take to stop physicians from pres
ing antibiotics in acute bronchitis [editorial]? Lancet 1995;345:665-6.

3 Orr PH, Scherer K, Macdonald A, Moffatt MEK. Randomized placebo-controlled trials of antibiotics for acute bronchitis: a critical review of the literature. J Fam Pract 1993;36:507-12.

4 Jónsson JS, Sigurdsson JA, Kristinsson KG, Gudnadottir M, Magnússon S. Acute bronchitis in adults: how close do we come to its etiology in general practice? Scand J Prim Health Care 1997;15:156-60.

5 Gíslason Th, Gíslason D, Blöndal Th. Astmi og öndunarfæraeinkenni medal 20-44 ára Íslendinga [Asthma and respiratory symptoms among 20-44 year old Icelanders]. Laknablaðið 1997;83:211-6. (Abstract in English.)

(Accepted 28 July 1998)
Funding: The study was supported by the division of

Gardabaer Health Centre, Gardatorg 7 IS-210 Gardabaer, Iceland

Jón Steinar Jónsson general practitioner

Pulmonary

Department,

Vífilsstadir, IS-210

Gardabaer, Iceland

Thorarinn Gíslason, chest physician

Davíd Gíslason,

allergologist

Department of Family Medicine,

Sólvangur Health

Centre, IS-220

Hafnarfjördur,

Iceland

Jóhann A

Sigurdsson,

professor

Correspondence to: Dr Jónsson

BMJ 1998;317:1433 